\title{
Nuclear factor erythroid-2 related factor 2 inhibits human disc nucleus pulpous cells apoptosis induced by excessive hydrogen peroxide
}

\author{
(iD) Hao Lin \\ (D) Yingxin Wang ${ }^{1}$ \\ (iD) Kaipeng Jing ${ }^{2}$ \\ (iD) Tingrui $W^{1}$ \\ (iD) Yanru Niu ${ }^{1}$ \\ (iD)insong Wei ${ }^{1}$
}

1. Orthopaedic Center, Affiliated Hospital of Guangdong Medical University, Zhanjiang, Guangdong, 524001, China. 2. Department of Nephrology, Affiliated Hospital of Guangdong Medical University, Zhanjiang, Guangdong, 524001, China.

\section{SUMMARY}

OBJECTIVE: Nuclear factor erythroid-2 related factor 2 (Nrf2)/ antioxidant response element (ARE) is a novel defensive pathway involved in the oxidative and chemical stress of cells. The aim of the study was to explore the role of Nrf2 on the apoptosis of human disc nucleus pulpous cells induced by hydrogen peroxide $\left(\mathrm{H}_{2} \mathrm{O}_{2}\right)$.

METHODS: The degeneration model of human intervertebral disc nucleus pulpous cells was established. The expression of Nrf2 was interfered with using sulforaphane (SFN); for that end, three groups were established: a blank group $\left(\mathrm{H}_{2} \mathrm{O}_{2}-/ S F N-\right)$, control group $\left(\mathrm{H}_{2} \mathrm{O}_{2}+/ \mathrm{SFN}-\right)$, and an experimental group $\left(\mathrm{H}_{2} \mathrm{O}_{2}+/ \mathrm{SFN}+\right)$. CCK8, Hoechst 33258 living cell staining was used to detect reactive oxygen species (ROS) content.

RESULTS: The apoptotic rates of the three groups were $[(0.40 \pm 0.46) \%],[(25.98 \pm 11.28) \%]$, and $[(3.83 \pm 2.06) \%$, respectively. The difference was statistically significant $(p<0.05)$. The relative content of ROS in the three groups was $[(100 \pm 7) \%],[(1538 \pm 91) \%]$, and $[(818 \pm 63) \%]$; the difference was statistically significant $(p<0.05)$. In Western blotting, Nrf2 content in the experimental group was higher than that in the control group.

CONCLUSION: Nrf2 exists in the nucleus pulpous cells of human intervertebral discs, which is related to the degeneration of the intervertebral disc. It has negative feedback regulation and can prevent the degeneration of the intervertebral disc by inhibiting the apoptosis of nucleus pulpous cells of human intervertebral discs caused by excessive ROS, which provides a new intervention strategy for the prevention and treatment of the degeneration of intervertebral discs.

KEYWORDS: NF-E2-related factor 2. Intervertebral disc degeneration. Spinal diseases. Nucleus pulposus.

\section{INTRODUCTION}

Degeneration is a chronic disease with high incidence $^{1}$ and is considered to be one of the main causes of chronic back pain ${ }^{2,3}$. Due to the change of the material and structure inside the intervertebral disc, the disc becomes unstable and its function is changed. Under the action of a slight external force, the fibrous 
ring of the disc is broken, the nucleus pulpous protrudes the fibrous ring, and the nerve root of the spinal cord is compressed, causing severe pain ${ }^{4}$. About $20 \%$ of patients in the world suffer from chronic lower back pain ${ }^{5}, 17 \%$ of them have obvious activity limitations due to severe pain ${ }^{6}$, which brings huge social and economic burden ${ }^{7}$. Degeneration is mainly treated by surgery $^{8}$. However, due to the complexity of patients with disc degeneration, there are often various complications and surgical failures after the operation, and the reoperation rate is about $13 \%{ }^{9}$. Therefore, understanding the molecular mechanism of the onset and development of degeneration and the key factors of regulation in its related pathways will provide a new strategy to prevent this condition.

It has been confirmed that oxidative stress is an important cause of disc degeneration. Excessive reactive oxygen species (ROS) can promote the apoptosis of functional cells of the intervertebral disc, accelerating the progression of degeneration10. The nuclear factor erythroid-2 related factor 2(Nrf2)/antioxidant response element (ARE) signaling pathway is an important way to avoid excessive ROS damage to cells ${ }^{11}$. Nrf2, as a key factor of the ARE signaling pathway, plays an important role in oxidative stress $^{12}$. Some studies have reported that Nrf2 plays an important role in the antioxidant damage of the liver, kidney, nerves, and other organs and tissues, inhibiting ROS-induced apoptosis ${ }^{13-15}$. However, most of the current studies on the relationship between Nrf2 and the intervertebral disc mainly focus on rat derived nucleus pulpous cells ${ }^{16-18}$. The effect of Nrf2 on human intervertebral disc nucleus pulpous cells is still unclear.

Therefore, the purpose of this study is to explore the relationship and significance of Nrf2 on the hydrogen peroxide $\left(\mathrm{H}_{2} \mathrm{O}_{2}\right)$-induced apoptosis of human disc nucleus pulpous cells and provide a new intervention strategy for the prevention and treatment of disc degeneration.

\section{METHODS}

Reagent

Sulforaphane (SFN, Meilun biology, China), 3\% hydrogen peroxide $\left(\mathrm{H}_{2} \mathrm{O}_{2}\right.$, Sigma Aldrich, USA), Hoechst 33258 (solar bio, China), active oxygen detection kit (solar bio, China), cell counting kit 8 (CCK8, Japanese colleague), double antibody (GIBCO, USA), fetal bovine serum (GIBCO, USA).

\section{Cell culture}

The human intervertebral disc nucleus pulpous cells were purchased from Wuhan prosaic Life Technology Co., Ltd. with the immunofluorescence identification report attached to them. Nucleus pulpous cells were cultured in DMEM/F12 medium mixed with 10\% fetal bovine serum and 1\% double-antibody in a wet incubator at $37^{\circ} \mathrm{C}$ and $5 \% \mathrm{CO}_{2}$.

\section{Establishment of the cell model}

Nucleus pulpous cells were seeded in 96 well plates at a density of $5 \times 10^{3}$ per well and cultured for 48 hours. $3 \% \mathrm{H}_{2} \mathrm{O}_{2}$ was diluted with DMEM/F12 medium gradient into 6 concentration groups of Oum, 100um, 150um, 200um, 250um, and 300um, which stimulated nucleus pulpous cells for 6 hours; the cell activity was detected by CCK8. The appropriate concentration was taken as the model to establish the concentration.

\section{Drug interventions}

The medullar cells were inoculated at a density of $5 \times 10^{3}$ per hole on a 96 well plate for 48 hours. The medullar cells established the degradation models, and different concentrations of SFN (OuM, $0.5 \mathrm{uM}$, 5UM, 10UM, 15UM, 20UM) were added for 6 hours. CCK8 detected cell activity in each concentration group and screened the best concentration of cell activity as an experimental group. At the same time, a blank group $\left(\mathrm{H}_{2} \mathrm{O}_{2}-\mathrm{SFN}-\right)$ and a control group $\left(\mathrm{H}_{2} \mathrm{O}_{2}{ }^{+/}\right.$ SFN-) were set up.

\section{Hoechst 3258 living cell staining}

The density of nucleus pulpous cells was $1.5 \times 10^{5}$ cells per pore in the 6-well plate, cultured for 48 hours. After $\mathrm{H}_{2} \mathrm{O}_{2}$ and SFN treatment, the original solution was removed, PBS was washed twice, Hoechst 33258 diluted at 1:1000 was added and placed in a wet incubator at $37^{\circ} \mathrm{C}$ for 20 minutes. The staining solution was removed, PBS was washed twice, and the fluorescence of cells in each group was observed by a fluorescence microscope.

\section{ROS content detection}

After the cells were attached to the wall, they were stimulated with $200 \mathrm{um} \mathrm{H}_{2} \mathrm{O}_{2}$ for 2 hours and then treated with SFN for 2 hours. The original solution was removed, PBS was washed once, 1:3000 diluted DCFH-DA $1 \mathrm{ml}$ was added, the dye was placed in a $37^{\circ} \mathrm{C}$ incubator for 20 minutes. The dye solution was removed, and the PBS washed three times. The 
expression of ROS was detected by fluorescence microscopy, and the fluorescence intensity was measured by enzyme labeling.

\section{Western blotting}

The cells were collected, scraped off with Ripa lysate (Biyuntian, China), split on ice for 30 minutes, vibrated once every 10 minutes, split by ultrasound twice, and then centrifuged. BCA protein quantitative Kit (Solar Bio, China) was used to detect the protein concentration and then balanced. 20ug protein per pore was separated by $10 \%$ gel, transferred to a PVDF membrane, sealed with $5 \%$ milk for 1 hour, then the membrane was cut according to the target protein quality (Nrf2, GAPDH), 1:1000 diluted GAPDH (cell signaling technology, CST, d16h11), Nrf2 (Abcam, ep1808y) were incubated overnight at $4^{\circ} \mathrm{C}$, TBST washed membrane three times, a second antibody (Biyuntian, China) was applied for one hour, TBST washed membrane three times, ECL substrate, chemical exposure.

\section{Statistical analysis}

All statistical analyses were carried out using the GraphPad Prism 6.0 Software (Analytic Technologies, Louisville, KY, USA). One way ANOVA was performed for comparisons between more than two groups. All the tests were two-sided and the value of $p<0.05$ (two-sided) was considered to be statistically significant.

\section{RESULTS}

Establishment of the degenerated cell model

CCK8 detection shows that $\mathrm{H}_{2} \mathrm{O}_{2}$ in the range of 100-300um can inhibit the activity of nucleus pulpous cells [(98.3 \pm 4.84$) \%,(87.36 \pm 3.41) \%,(52.02 \pm 9.15) \%$, $(9.19 \pm 1.37) \%,(4.45 \pm 1.07) \%]$ in a concentration-dependent manner after 6 hours of use (Figure 1A). With the increase of $\mathrm{H}_{2} \mathrm{O}_{2}$ concentration, the apoptosis of nucleus pulpous cells is more obvious. The activity of nucleus pulpous cells in the $200 \mathrm{uM}$ group was (52.02 \pm 9.15$) \%$, which was used to model nucleus pulpous cells.

After modeling, SFN (Nrf2 activator) with a concentration of 0.5-20um was added. The results showed that the relative activity of nucleus pulpous cells [(121.94 \pm 3.1$) \%,(141.43 \pm 11.54) \%,(132.99 \pm$ $10.42) \%$, $(126.75 \pm 4.86) \%$, $(114.6 \pm 5.19) \%]$ was higher than that of the OuM Group [(100 \pm 13.23$) \%]$, and the apoptosis of cells was significantly inhibited. 5uM was admitted as the drug intervention concentration (Figure 1B).

\section{FIGURE 1}

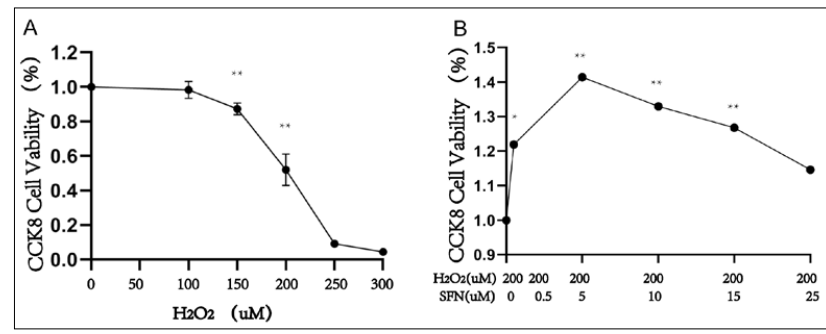

Cell viability detection by CCK8.(A) CCK8 was added to the nucleus pulposus cells treated with different concentrations of $\mathrm{H}_{2} \mathrm{O}_{2}$ for 6 hours. (B) The nucleus pulposus cells were treated with $\mathrm{H}_{2} \mathrm{O}_{2}$ at 200 um for 6 hours, then the SFN of different concentrations of the Nrf2 activator was replaced for 6 hours, and CCK8 was added to analyze the cell activity.

${ }^{\star} P<0.05,{ }^{, *} P<0.001$

Nrf2 activator can inhibit apoptosis of nucleus pulpous cells caused by ROS excess.

In order to better understand the inhibitory effect of Nrf2 on the apoptosis of nucleus pulposus cells, Hoechst 33258 was used for living cell staining (Figures 2A and 2B). The results showed that the apoptosis rates of the blank group, control group, and experimental group were [(0.40 \pm 0.46$) \%]$, [(25.98 \pm 11.28$) \%]$, [(3.83 \pm 2.06$) \%]$, respectively. Compared with the control group, the nucleus pulposus cells in the blank group basically did not show the concentrated apoptosis cells. After $\mathrm{H}_{2} \mathrm{O}_{2}$ peroxide stimulation, the apoptosis rate in the control group was up-regulated, and the concentrated apoptosis cells were increased under the microscope. Compared with the control group, the apoptosis of the experimental group was significantly inhibited after NRf2 activator treatment, and the concentrated apoptosis cells were reduced under the microscope, with significant statistical differences. (Figures 2C and 2D) The content of ROS was detected by a DCFH-DA probe, and the fluorescence intensity was measured by an enzyme labeling instrument. The relative content of ROS in the three groups (in relation to the blank group) was [(100 \pm 7$) \%]$, [(1538 \pm 91$) \%]$, and $[(818 \pm 63) \%]$. Compared with the blank group, the ROS content increased, and green fluorescence increased after $\mathrm{H}_{2} \mathrm{O}_{2}$ peroxide stimulation in the control group; compared with the control group, ROS content decreased and green fluorescence decreased after Nrf2 activator intervention in the experimental 
and control groups. All of the above differences were statistically significant. $\mathrm{H}_{2} \mathrm{O}_{2}$ can up-regulate ROS content and induce apoptosis. In contrast, the Nrf2 activator can inhibit the progress of apoptosis by down-regulating ROS content.

\section{FIGURE 2}

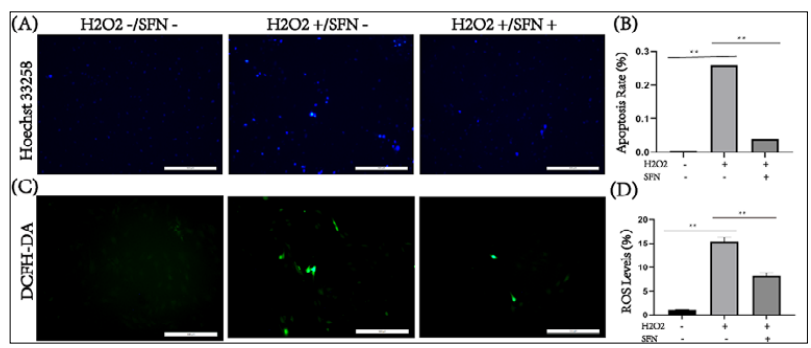

Hoechst 33258 staining. (A)The dark blue in the picture is an apoptotic cell. (B) The apoptotic rate of the blank group is significantly higher than that of the control group, and the apoptotic rate of the experimental group is significantly lower than that of the control group, with statistical significance $(P<0.001)$. (C) The content of ROS was measured by DCFH-DA. Under a fluorescence microscope, (D) fluorescence intensity was detected by the fluorescence enzyme. The content of ROS in the experimental group was lower than that in the control group $(P<0.001)$. Note: Apoptosis rate $=$ number of apoptotic cells/total number of visual field cells; ROS content $\%=$ absorbance value of each sample/average absorbance value of the blank group. Note: apoptosis rate $=$ number of apoptotic cells/total cells .

Nrf2 activator SFN up-regulates Nrf2 expression in nucleus pulposus cells

Western blotting (Figure 3) showed that Nrf2 was present in normal nucleus pulposus cells, and Nrf2 activator could up-regulate the expression of Nrf2 protein in the nucleus pulposus cells. A grayscale analysis showed that Nrf2 in the experimental group increased from $57 \%$ to $82 \%$.

\section{FIGURE 3}

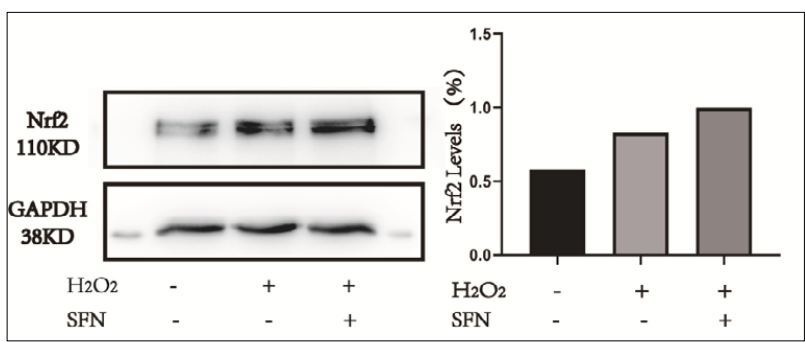

Effect of $\mathrm{H}_{2} \mathrm{O}_{2}$ and SFN on Nrf2 and GAPDH protein expression. The expression of Nrf2 and $\mathrm{G}^{2} \mathrm{APDH}$ protein was analyzed by Western blot after 6 hours of treatment with 200 um $\mathrm{H}_{2} \mathrm{O}_{2}$ and 5 um SFN.

\section{DISCUSSION}

In this experiment, $\mathrm{H}_{2} \mathrm{O}_{2}$ was used to stimulate the cells of the nucleus pulpous of human intervertebral discs to create an imbalance of the redox environment. The activity of CCK8 decreased by about $50 \%$ at the concentration of 200um. Compared with previous studies, the concentration of the model is consistent, and the model is effective ${ }^{19,20}$. CCK8 screened the appropriate concentration of Nrf2 activator intervention. In the experiment, it can be seen that Nrf2 activator can significantly inhibit the decline of cell viability caused by $\mathrm{H}_{2} \mathrm{O}_{2}$, of which the effect is most obvious when the concentration is $5 \mathrm{um}$. This was admitted as the appropriate concentration for the next experiment.

Degeneration is one of the main causes of chronic low back pain. Haefeli et al. ${ }^{21}$ found in 41 routine autopsies ( 7 months to 88 years old) in 2006 that extensive macroscopic changes in the disc had occurred in the second decade of life. Healthy people also have low-grade disc degeneration, which seriously affects human health. Oxidative stress inhibited the proliferation of human nucleus pulpous cells and induced premature senescence ${ }^{22}$. Suzuki et al. ${ }^{23}$ believe that excessive ROS is the treatment target of disc degeneration. When the redox balance is destroyed, the anti-oxidation system of cells will take effect, and the cells will return to redox homeostasis. The mechanism of cytoprotection is controlled by the transcription of the Nrf2-ARE pathway ${ }^{24}$.

The results show that excessive ROS can induce apoptosis of human disc nucleus pulposus cells and promote the degeneration of the human disc. In order to explore the role of $\mathrm{Nrf} 2$ and ROS in the apoptosis of human disc nucleus pulpous cells. In this study, compared with the control group, the blank group showed a significant increase in the concentration of blue fluorescent cells in the Hoechst 33258 staining control group, which were apoptotic human disc nucleus pulpous cells. The green fluorescence intensity of the DCFH-DA staining group was also up-regulated, and the green fluorescence was ROS content.

There are some strengths and limitations to this study. The strength was that the results suggested that Nrf2 can inhibit apoptosis of nucleus pulpous cells induced by ROS. The alternative signaling pathways which may be involved in the apoptosis of human disc nucleus pulpous cells induced by $\mathrm{H}_{2} \mathrm{O}_{2}$ include p38, STAT3, and interferon regulatory factor. Therefore, we can't exclude the possibility that another signaling pathway was also involved in the $\mathrm{H}_{2} \mathrm{O}_{2}$-induced apoptosis of human disc nucleus pulpous cells. 


\section{CONCLUSION}

Nrf2 can regulate the antioxidant system in the human disc nucleus pulpous cells.

\section{Acknowledgments}

This study was supported by Zhanjiang science and technology plan project (2016a01016); National Natural Science Foundation Project (81600698); Guangdong Natural Science Foundation (2017)(A030313833); Research Fund Project of Guangdong Medical University (m2017014)

\section{Competing interests}

The authors declare that they have no competing interests.

\section{Author's Contribution}

Conceptualization, Hao Lin; formal analysis, Yingxin Wang; writing of the original draft, Hao Lin; review and editing, Kaipeng Jing and Tingrui Wu; supervision, Yanru Niu; funding acquisition, Jinsong Wei.

\section{RESUMO}

OBJETIVO: O fator 2 relacionado a NF-E2 (Nrf2)/elemento de resposta antioxidante (ARE) é uma nova via defensiva envolvida no estresse oxidativo e químico das células. O objetivo deste estudo foi explorar o papel do Nrf2 na apoptose das células do núcleo pulposo do disco humano induzida pelo peróxido de hidrogênio $\left(\mathrm{H}_{2} \mathrm{O}_{2}\right)$.

MÉTODOs: O modelo de degeneração das células do núcleo pulposo do disco intervertebral humano foi estabelecido. A expressão do Nrf2 foi interferida utilizando-se sulforafano (SFN). Para isso foram estabelecidos três grupos: um grupo vazio ( $\mathrm{H}_{2} \mathrm{O}_{2}-/ S F N-$ ), um grupo de controle $\left(\mathrm{H}_{2} \mathrm{O}_{2}+/ \mathrm{SFN}-\right)$, e um grupo experimental $\left(\mathrm{H}_{2} \mathrm{O}_{2}+/ \mathrm{SFN}+\right)$. Utilizando CCK8 e Hoechst 33258, o conteúdo de espécies reativas de oxigênio (ERO) foi detectado.

RESULTADOS: As taxas de apoptose dos três grupos foram $[(0,40 \pm 0,46) \%]$, $[(25,98 \pm 11,28 \%)]$ e $[(3,83 \pm 2,06) \%]$, respectivamente. A diferença apresentou significância estatística $(p<0,05)$. O conteúdo relativo de ERO nos três grupos foi [(100 \pm 7$) \%],[(1538 \pm 91 \%)]$, e [(818ะ63\%); a diferença foi estatisticamente significativa $(p<0,05)$. O método de Western blotting indicou um maior conteúdo de Nrf2 no grupo experimental do que no grupo de controle.

CONCLUSÃo: O Nrf2 existe em células do núcleo pulposo do disco intervertebral humano, que estão relacionadas à degeneração do disco intervertebral. Ele apresenta regulação por feedback negativo e pode evitar a degeneração do disco intervertebral inibindo a apoptose de células do núcleo pulposo do disco causada por excesso de ERO. Essa informação proporciona uma nova estratégia de intervenção para a prevenção e o tratamento da degeneração do disco intervertebral.

PALAVRAS-CHAVE: Fator 2 relacionado a NF-E2. Degeneração do disco intervertebral. Doenças da coluna vertebral. Núcleo pulposo.

\section{REFERENCES}

1. Brazilian Medical Association, Silvinato A, Simões RS, Buzzini RF, Bernardo WM. Lumbar herniated disc treatment with percutaneous hydrodiscectomy. Rev Assoc Med Bras (1992). 2018;64(9):778-82.

2. Vergroesen PP, Kingma I, Emanuel KS, Hoogendoorn RJ, Welting T], van Royen BJ, et al. Mechanics and biology in intervertebral disc degeneration: a vicious circle. Osteoarthritis Cartilage. 2015;23(7):1057-70.

3. Zhao R, Liu W, Xia T, Yang L. Disordered mechanical stress and tissue engineering therapies in intervertebral disc degeneration. Polymers (Basel). 2019;11(7). pii: E1151. doi: 10.3390/polym11071151.

4. Deyo RA, Loeser (D, Bigos S|. Herniated lumbar intervertebral disk. Ann Intern Med. 1990;112(8):598-603.

5. Joaquim AF, Botelho RV, Mudo ML, Almeida AS, Bernardo WM. Lumbar herniated disc: endoscopic discectomy treatment. Rev Assoc Med Bras (1992). 2018;64(5):397-407.

6. Hoy D, Bain C, Williams G, March L, Brooks P, Blyth F, et al. A systematic review of the global prevalence of low back pain. Arthritis Rheum. 2012;64(6):2028-37.

7. Clark S, Horton R. Low back pain: a major global challenge. Lancet. 2018;391(10137):2302.

8. Burton AK, Tillotson KM, Cleary J. Single-blind randomised controlled tria of chemonucleolysis and manipulation in the treatment of symptomatic lumbar disc herniation. Eur Spine |. 2000;9(3):202-7.
9. Overdevest GM, Peul WC, Brand R, Koes BW, Bartels RH, Tan WF, et al; Leiden-The Hague Spine Intervention Prognostic Study Group. Tubular discectomy versus conventional microdiscectomy for the treatment of lumbar disc herniation: long-term results of a randomised controlled trial. J Neurol Neurosurg Psychiatry. 2017;88(12):1008-16.

10. Sun HP, Li A, Xu Y, Pan CW. Secular trends of reduced visual acuity from 1985 to 2010 and disease burden projection for 2020 and 2030 among primary and secondary school students in China. JAMA Ophthalmol. 2015;133(3):262-8.

11. Tu W, Wang H, Li S, Liu Q, Sha H. The anti-inflammatory and anti-oxidant mechanisms of the Keap1/Nrf2/ARE signaling pathway in chronic diseases. Aging Dis. 2019;10(3):637-51.

12. Vomhof-Dekrey EE, Picklo MJ Sr. The Nrf2-antioxidant response element pathway: a target for regulating energy metabolism. J Nutr Biochem. 2012;23(10):1201-6.

13. Gong DJ, Wang L, Yang YY, Zhang JJ, Liu XH. Diabetes aggravates renal ischemia and reperfusion injury in rats by exacerbating oxidative stress, inflammation, and apoptosis. Ren Fail. 2019;41(1):750-61.

14. Hoang TT, Johnson DA, Raines RT, Johnson JA. Angiogenin activates the astrocytic Nrf2/antioxidant-response element pathway and thereby protects murine neurons from oxidative stress. | Biol Chem. 2019;294(41):15095-103. 
15. Liu C, Cui Y, Pi F, Guo Y, Cheng Y, Qian H. Torularhodin ameliorates oxidative activity in vitro and d-galactose-induced liver injury via the $\mathrm{Nrf2/HO}-1$ signaling pathway in vivo. J Agric Food Chem. 2019;67(36):10059-68.

16. Lin I, Chen I, Zhang Z, Xu T, Shao Z, Wang X, et al. Luteoloside inhibits IL-1 $\beta$-induced apoptosis and catabolism in nucleus pulposus cells and ameliorates intervertebral disk degeneration. Front Pharmacol. 2019;10:868.

17. Wang J, Huang C, Lin Z, Pan X, Chen J, Zheng G, et al. Polydatin suppresses nucleus pulposus cell senescence, promotes matrix homeostasis and attenuates intervertebral disc degeneration in rats. I Cell Mol Med. 2018;22(11):5720-31.

18. Wang K, Hu S, Wang B, Wang J, Wang X, Xu C. Genistein protects intervertebral discs from degeneration via Nrf2-mediated antioxidant defense system: an in vitro and in vivo study. J Cell Physiol. 2019.

19. Chen JW, Ni BB, Li B, Yang YH, Jiang SD, Jiang LS. The responses of autophagy and apoptosis to oxidative stress in nucleus pulposus cells: implications for disc degeneration. Cell Physiol Biochem. 2014;34(4):1175-89.
20. Chu H, Yu H, Ren D, Zhu K, Huang H. Plumbagin exerts protective effects in nucleus pulposus cells by attenuating hydrogen peroxide-induced oxidative stress, inflammation and apoptosis through NF-kB and Nrf-2. Int | Mol Med. 2016;37(6):1669-76.

21. Haefeli M, Kalberer F, Saegesser D, Nerlich AG, Boos N, Paesold G. The course of macroscopic degeneration in the human lumbar intervertebral disc. Spine (Phila Pa 1976). 2006;31(14):1522-31.

22. Adams MA, Roughley PI. What is intervertebral disc degeneration, and what causes it? Spine (Phila Pa 1976). 2006;31(18):2151-61.

23. Suzuki S, Fujita N, Hosogane N, Watanabe K, Ishii K, Toyama Y, et al. Excessive reactive oxygen species are therapeutic targets for intervertebral disc degeneration. Arthritis Res Ther. 2015;17:316.

24. Shaw $P$, Chattopadhyay A. Nrf2-ARE signaling in cellular protection: mechanism of action and the regulatory mechanisms. / Cell Physiol. 2020;235(4):3119-30. 